Proceedings

\title{
Photochromic Azoderivatives for Acetylcholinesterase Inhibition ${ }^{\dagger}$
}

\author{
Brunella Biscussi, Maria Alejandra Sequeira * and Ana Paula Murray \\ Instituto de Química del Sur (INQUISUR-CONICET), Chemistry Department, Universidad Nacional del Sur, \\ Av. Alem 1253, B8000CPB Bahía Blanca, Argentina; brunella.biscussi@uns.edu.ar (B.B.); \\ apmurray@uns.edu.ar (A.P.M.) \\ * Correspondence: alejandra.sequeira@uns.edu.ar \\ + Presented at the 23rd International Electronic Conference on Synthetic Organic Chemistry, \\ 15 November-15 December 2019; Available online: https://ecsoc-23.sciforum.net/.
}

Published: 14 November 2019

\begin{abstract}
We present microwave-assisted synthesis and in vitro acetylcholinesterase inhibition of di-PRLC ${ }_{4} \mathrm{OAzo}$, a new azoderivative designed on the basis of aza-stilbene active compounds, already reported by the group. From the total series of azoderivatives synthetized, di-PRLC 4 OAzo showed the powerful in vitro enzymatic response for its $(E)$ isomer (IC $\left.{ }_{50}: 1.08 \mu \mathrm{M}\right)$ by Ellman's assay, beside a stable photostationary state monitored by UV/Vis absorption spectroscopy, indicating it might be an efficient photo-responsible probe to remote control the activity of the enzyme.
\end{abstract}

Keywords: microwave-assisted synthesis; acetylcholinesterase; azobenzene; photomodulation

\section{Introduction}

Cholinesterase inhibitors (ChEI) play a significant role in enhancing synaptic cholinergic activity avoiding cholinergic poisoning, and consequently have therapeutic relevance related to Alzheimer's disease (AD), myasthenia gravis, and glaucoma [1]. In this sense, photochromic ChEI have become interesting due to the expansion of photopharmacological approach towards the remote control of acetylcholinesterase (AChE), a main target for studying the activity of neural networks due to its fast diffusion-controlled kinetics [2]. Nowadays, the control of synaptic communication with light has become a prime topic of investigation due to its noninvasive application, with very high temporal and spatial precision [3,4]. The Trauner group demonstrated photocontrol of AChE using an azobenzene derivative based on the drug Tacrine, approved for early stage AD [5]. The "azologization" approach, derived from "azobenzene" combined with "analogization", support that azobenzene can mimic structural motifs ("azosteres") found in drugs or drug candidates such as stilbenes, (heterocyclic) N-aryl benzamides, benzyl phenyl (thio)ethers, benzyl anilines, and 1,2diaryl ethanes, offering the possibility for light sensitization and light-dependent control of its functions [6]. Inspired in this concept of "azologization", we improved the rational introduction of a disubstituted azobenzene group into the structure of a designed aza-stilbene compound active as dual ChEI, previously reported by our group [7] (Figure 1). Electron-donating substituents in the azobenzene moiety allow efficient photoisomerization in aqueous solutions with slow thermal backisomerization [8]. 


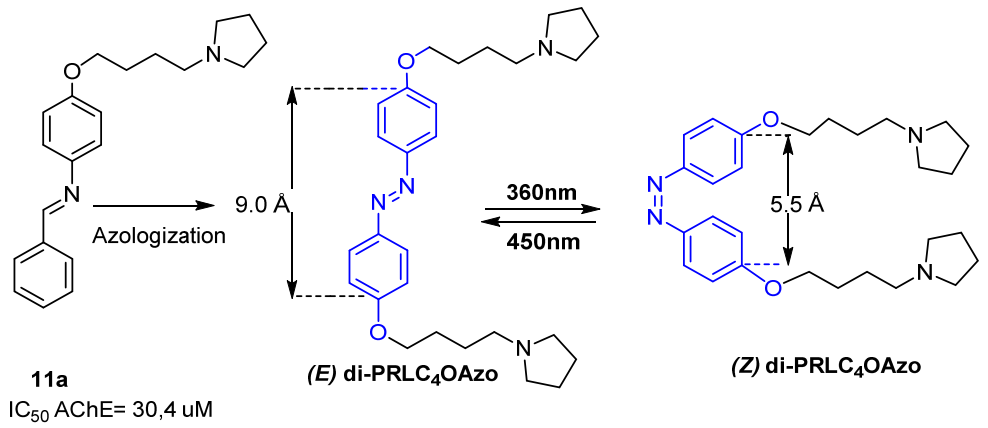

Figure 1. Application of the azologization principle to 11a, a reported aza-stilbene active as dual ChEI.

Versatile microwave-assisted synthesis allows us the generation of molecular diversity from the same azobenzene precursor in a fast way. In this work, we present microwave-assisted synthesis and structural characterization of a new azobenzene-based compound with potential application as reversible photochromic AChE inhibitor: 1,2-bis(4-(4-(pyrrolidin-1-yl)butoxy)phenyl)diazene (diPRLC ${ }_{4} \mathrm{OAzo}$ ), which showed in vitro enzymatic response for its $(E)$ isomer. Ellman's assay was performed for measuring AChE activity in the presence of the reversible photoswitchable blocker, whose in vitro photoisomerization efficiency was evaluated by UV/Vis absorption spectroscopy. The aim of this work is to contribute to the development of new synthetic photomodulable drugs for the treatment of AD.

\section{Experimental Procedure}

\subsection{Materials and Synthesis}

All solvents used were purified by distillation, after drying over a specific agent. The drying agents used were previously activated by heating in an oven. Acetonitrile was dried over $\mathrm{K}_{2} \mathrm{CO}_{3}$ and distilled immediately before use. DMF was distilled and dry by keeping it over 4A molecular sieves under nitrogen atmosphere. The progress of the reactions was controlled using silica gel-60 F 254 chromatofoils (Merck). The development of thin layer chromatograms was performed by visualization with ultraviolet light of wavelengths $254 \mathrm{~nm}$ and/or in $p$-anisaldehyde developing stain.

Conventional synthesis of 4,4'-dihydroxyazobenzene (1). Synthesis of 4,4'-dihydroxyazobenzene was carried out according to the method described in bibliography [9] of Willstatter and Benz [10]. In a two-mouth ball containing a magnetic stirrer, $5.00 \mathrm{~g}$ of $p$-nitrophenol $(35.95 \mathrm{mmol})$ was added to a solution containing $25 \mathrm{~g}$ of $\mathrm{KOH}$ ( $380 \mathrm{mmol})$ in $5 \mathrm{~mL}$ of MilliQ water. The reaction mixture was refluxed at $120^{\circ} \mathrm{C}$ and the temperature was increased slowly for $1 \mathrm{~h}$ to $195-200{ }^{\circ} \mathrm{C}$. Once the reaction was completed, it began vigorously to give a brown viscous liquid with a large number of developing bubbles. The crude product was dissolved in $40 \mathrm{~mL}$ of water. The solution was acidified to $\mathrm{pH} 3$ by adding a solution of concentrated $\mathrm{HCl}$, a dark red reaction crude was observed, and extraction was carried out with diethyl ether. The combined ether extracts were dried over $\mathrm{Na}_{2} \mathrm{SO}_{4}$ overnight. The solvent was removed by reduced pressure, and the crude product was obtained as a solid. It was recrystallized from $50 \%(v / v)$ aqueous solution of ethanol. When observing differences between experimental BP $\left(120^{\circ} \mathrm{C}\right)$ and the theoretical one $\left(204-214^{\circ} \mathrm{C}\right)$ [11], recrystallization was repeated up to a total of 10 times, to give yellow crystals of compound 1 . The purification was monitored by TLC silica gel, using as eluents hexane:ethyl acetate (1:1). R.f. $=0.32$. Compound $\mathbf{1}$, soluble in acetonitrile and acetone, was obtained in 10\% yield. ${ }^{1} \mathrm{H}-\mathrm{RMN}\left(\mathrm{CD}_{3} \mathrm{CN}, 300 \mathrm{MHz}\right) \delta(\mathrm{ppm}): 6.95\left(\mathrm{~d}, 4 \mathrm{H}, J^{3}=8.90\right.$ $\mathrm{Hz}, \mathrm{Ar}-\mathrm{H}), 7.77\left(\mathrm{~d}, 4 \mathrm{H}, J^{3}=8.91 \mathrm{~Hz}, \mathrm{Ar}-\mathrm{H}\right), 8.12(\mathrm{~s}, 2 \mathrm{H}) .{ }^{13} \mathrm{C}-\mathrm{RMN}\left(\mathrm{CD}_{3} \mathrm{CN}\right) \delta(\mathrm{ppm}): 116.71,118.24$, $125,21,160.42$.

Microwave-assisted synthesis of 1,2-bis(4-(4-bromobutoxy)phenyl)diazene (2). To a solution containing $0.1 \mathrm{mmol}$ of 4,4'-dihydroxyazobenzene and $0.35 \mathrm{mmol}$ of $\mathrm{K}_{2} \mathrm{CO}_{3}$ in $4 \mathrm{~mL}$ of acetonitrile placed in a microwave reaction glass tube with a magnetic stirrer included, $0.4 \mathrm{mmol}$ of 1, 4-dibromobutane was added. The tube was placed in the microwave reactor (CEM Discover), at $150 \mathrm{~W}$ and $80^{\circ} \mathrm{C}$ for $20 \mathrm{~min}$. 
The obtaining of the desired product was confirmed by TLC. The solvent was removed by reduced pressure, and the crude product was obtained as a solid. This solid was further purified by column chromatography on neutral aluminum oxide (Fluka AG, Bursch SG), using as eluents hexane: diethyl ether, and 2 was recovered as a yellowish solid in $65 \%$ yield. ${ }^{1} \mathrm{H}-\mathrm{RMN}\left(\mathrm{CDCl}_{3}, 300 \mathrm{MHz}\right) \delta(\mathrm{ppm})$ : $2.08\left(\mathrm{~m}, 8 \mathrm{H}, \mathrm{CH}_{2}\right), 3.50\left(\mathrm{t}, 4 \mathrm{H}, \mathrm{CH}_{2}\right), 4.07\left(\mathrm{t}, 4 \mathrm{H}, \mathrm{CH}_{2}\right), 6.99\left(\mathrm{~d}, 4 \mathrm{H}, J^{3}=8.89 \mathrm{~Hz}, \mathrm{Ar}-\mathrm{H}\right) ; 7.88\left(\mathrm{~d}, 4 \mathrm{H}, J^{3}=\right.$ $8.90 \mathrm{~Hz}, \mathrm{Ar}-\mathrm{H}) .{ }^{13} \mathrm{C}-\mathrm{RMN}\left(\mathrm{CDCl}_{3}\right) \delta$ (ppm): 27.99, 29.56, 33.51, 67.28, 114.78, 124.50, 147.22, 161.00.

Microwave-assisted synthesis of 1,2-bis(4-(4-(pyrrolidin-1-yl)butoxy)phenyl)diazene (di-PRLC $4 \mathrm{OAzo}$ ). To a solution containing $0.1 \mathrm{mmol}$ of 2 and $0.5 \mathrm{mmol}$ of $\mathrm{K}_{2} \mathrm{CO}_{3}$ in $4 \mathrm{~mL}$ of dry DMF placed in a microwave reaction glass tube containing a magnetic stirrer, it was added $0.4 \mathrm{mmol}$ of pyrrolidine. The glass tube was placed in the microwave reactor at $150 \mathrm{~W}, 80^{\circ} \mathrm{C}$, for $20 \mathrm{~min}$ until observing total conversion by TLC. The solvent was evaporated under reduced pressure using a SpeedVac Concentrator (SPD111V, Thermo Savant) to give di-PRLC 4 OAzo as a yellow solid without further purification in $99 \%$ yield. ${ }^{1} \mathrm{H}-\mathrm{RMN}\left(\mathrm{CDCl}_{3}, 300 \mathrm{MHz}\right) \delta(\mathrm{ppm}): 1.79\left(\mathrm{~m}, 16 \mathrm{H}, \mathrm{CH}_{2}\right), 2.53\left(\mathrm{~m}, 12 \mathrm{H}, \mathrm{CH}_{2}\right)$, $4.05\left(\mathrm{t}, 4 \mathrm{H}, \mathrm{CH}_{2}\right), 6.99\left(\mathrm{~d}, 4 \mathrm{H}, \mathrm{J}^{3}=8.89 \mathrm{~Hz}, \mathrm{Ar}-\mathrm{H}\right), 7.84\left(\mathrm{~d}, 4 \mathrm{H}, J^{3}=8.90 \mathrm{~Hz}, \mathrm{Ar}-\mathrm{H}\right) .{ }^{13} \mathrm{C}-\mathrm{RMN}\left(\mathrm{CDCl}_{3}\right) \delta$ (ppm): 23.71, 25.69, 27.51, 54.35, 56.29, 68.20, 114.81, 124.44, 147.12, 161.22.

\subsection{Methods}

NMR Spectroscopy. NMR spectra were recorded on a Bruker ARX 300 spectrometer $(300 \mathrm{MHz}$ and $75 \mathrm{MHz}$ for ${ }^{1} \mathrm{H}$ and ${ }^{13} \mathrm{C}$, respectively). $\mathrm{CDCl}_{3}$ was used as solvent with TMS as internal standard.

$U V$-Vis Spectroscopy. Switching experiments were done with an $8 \mathrm{~W}$ mercury arc lamp with filter of $360 \mathrm{~nm}$ from Pleuger Antwerp Brussels and a white light bulb of $60 \mathrm{~W}$. UV-vis spectroscopy data were recorded on a JASCO V-630BIO (Tokyo, Japan) Spectrophotometer equipped with an EHCS760 Peltier.

Quantitative AChE inhibition assay. AChE from electric eel (500 U, Sigma, Buenos Aires, Argentina) was used as a source of acetylcholinesterase. The inhibitory activity of AChE was determined in vitro using the Ellman's spectrophotometric method with minor modifications [12,13]. The absorbance was recorded at $405 \mathrm{~nm}$ for $120 \mathrm{~s}$ at $27^{\circ} \mathrm{C}$. Enzymatic activity was calculated by comparing the reaction rates between the sample and the blank. The sample concentration reflecting $50 \%$ inhibition $\left(\mathrm{IC}_{50}\right)$ was calculated by nonlinear regression of the response curve versus $\log$ (concentration), using GraphPadPrism 5. Tacrine was used as the reference inhibitor.

\subsection{Results and Discussion}

In order to obtain azoderivatives with potential application as reversible photochromic AChE inhibitor, we decided to exchange the aza-stilbene structure by a fotomodulable azobenzene core, preserving the successfully linker design for the catalytic site (CAS) of the enzyme, consisting in a hydrocarbon chain connected to a tertiary amine already developed by the group [14]. The peripheral anionic site (PAS) of AChE would be the possible target of interaction with the azobenzene structure being the potential photomodulable site. Herein, the azoderivative di-PRLC 4 OAzo presented is disubstituted at 4, 4' position with four-hydrocarbon chain connected to pyrrolidine.

The preparation of di-PRLC ${ }_{4} \mathrm{OAzo}$ was carried out using the procedures shown in Scheme 1. The first synthetic step was conducted in a conventional manner, because microwave reactor was not initially available. Otherwise, at the next steps azoderivatives were prepared in high yields and in shorter reaction times using the optimized microwave heating method, showing great yield advantages and reducing purifications stages over the conventional method.

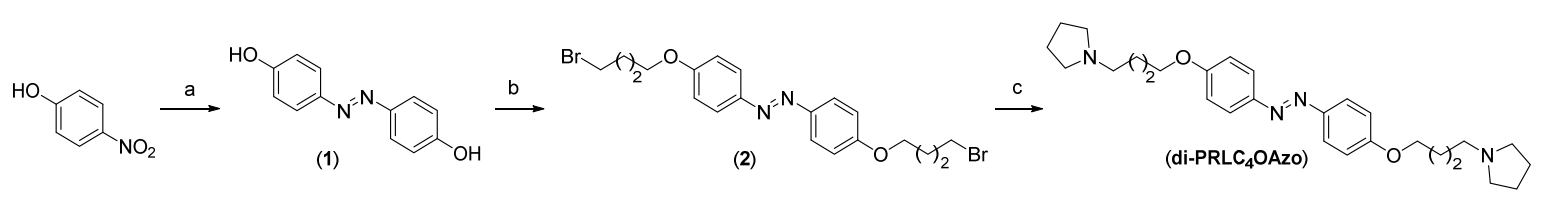

Scheme 1. Synthetic Pathway to di-PRLC4OAzo. (a) $\mathrm{KOH} / \mathrm{H}_{2} \mathrm{O}, 120{ }^{\circ} \mathrm{C}, 1$ h. (b) $\mathrm{Br}\left(\mathrm{CH}_{2}\right)_{4} \mathrm{Br}, \mathrm{K}_{2} \mathrm{CO}_{3}$, $\mathrm{CH}_{3} \mathrm{CN}$, MW 20'. (c) pyrrolidine, $\mathrm{K}_{2} \mathrm{CO}_{3}, \mathrm{DMF}$, MW $25^{\prime}$. 
The duplication of the linker at 4, 4' position, as well as the introduction of oxygen atoms as connectors between the azobenzene moiety and the linkers, were designed for the propose of allowing efficient photoisomerization with slow thermal back-isomerization. Upon isomerization from the $E$-form to the Z-form, the distance between the 4 and $4^{\prime}$ positions shortens by about $3 \AA$. This remarkably large change (the $E$ azobenzene molecule itself is $9 \AA$ long) can be amplified with appropriate substitution (Figure 2a).

In methanol, yellow solution of di-PRLC ${ }_{4} \mathrm{OAzo}(E)$ changed to orange upon UV-light illumination ( $360 \mathrm{~nm}, 8$ watts, $5 \mathrm{~min}$ ), when the stabilized photostationary state (pss) of $E: Z$ (12:88) was reached, named di-PRLC ${ }_{4} \mathrm{OAzo}(Z)$ (orange solution). The photoconvertion ratio from $E$ to $Z$ isomer was evidenced by UV-Vis spectroscopy (Figure $2 b$ ). The UV-Vis spectra of di-PRLC 4 OAzo (E) showed a characteristic $\pi-\pi^{*}$ transition centered in $355 \mathrm{~nm}$ and a small band at $446 \mathrm{~nm}$

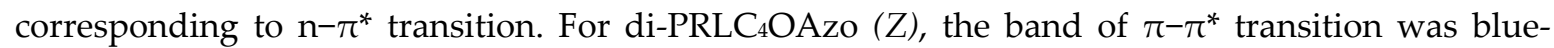
shifted to $314 \mathrm{~nm}$, and the band corresponding to $\mathrm{n}-\pi^{*}$ transition at $446 \mathrm{~nm}$ was more evident. Thermal $Z \rightarrow E$ isomerization was slow enough to allow the evaluation of $Z$ isomer at the stabilized pss (stable $10 \mathrm{~h}$ in darkness). This experiment suggested that di-PRLC ${ }_{4} \mathrm{OAzo}$ could be used as optically controlled probe [14].
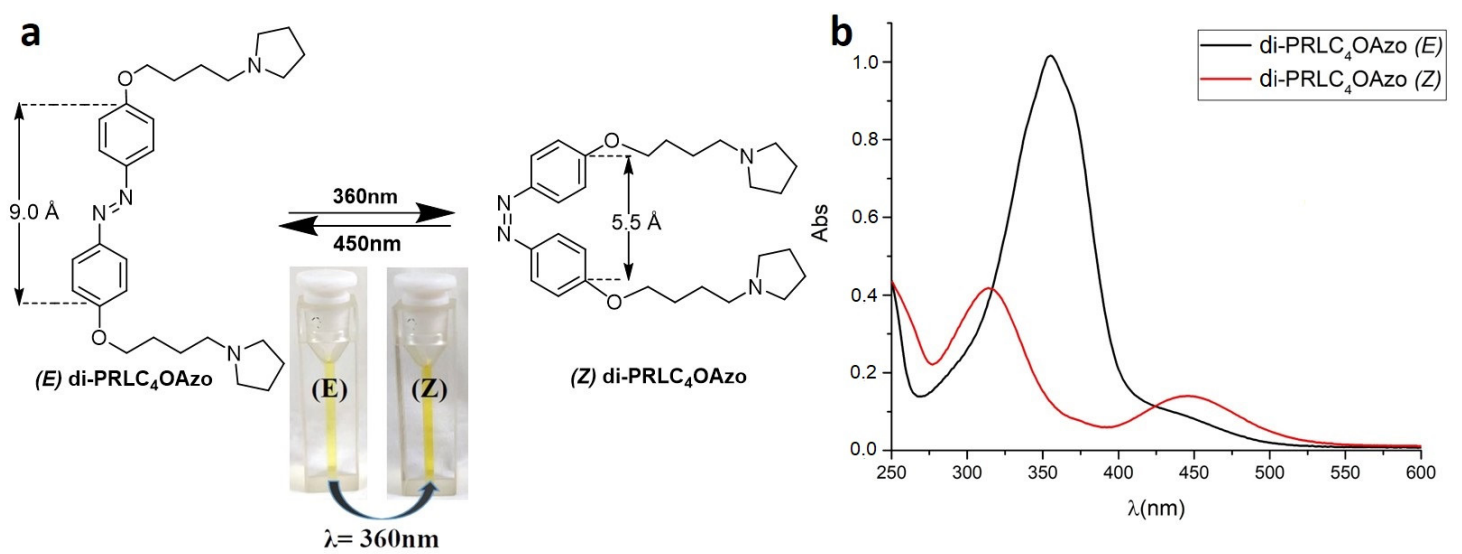

Figure 2. (a) Photoisomerization of di-PRLC ${ }_{4} \mathrm{OAzo}$. (b) UV-Vis spectra of di-PRLC ${ }_{4} \mathrm{OAzo}$ before ( ) and after ( ) UV-light illumination (360 nm, 8 watts, $5 \mathrm{~min}$ ) in methanol (50 $\mu \mathrm{M})$.

The AChE inhibitory activity of di-PRLC 4 OAzo was evaluated in vitro by the Ellman spectrophotometric method with slight modifications. Its $E$ isomer showed a IC50 value of $1.08 \mu \mathrm{M}$ $\left(\log \mathrm{IC}_{50} \pm\right.$ DS: $\left.0.037 \pm 0.030\right)$ for AChE inhibition, displaying a sharply more powerful in vitro enzymatic response than its aza-stilbene analogue, compound 11a, with a previous reported IC50 = $30.4 \mu \mathrm{M}\left(\log \mathrm{IC}_{50} \pm \mathrm{DS}: 1.489 \pm 0.0456\right)$ [15].

\section{Conclusions}

In conclusion, from several azoderivatives optimally synthesized by microwave-assisted synthesis, we obtained in high yields and short reaction times, di-PRLC 4 OAzo, a photomodulable azobenzene core disubstituted at 4, 4' position with four-hydrocarbon chain connected to pyrrolidine. The rational design promoted conversion to the $Z$ isomer with brief UV light exposure, showing efficient photoisomerization with slow thermal back-isomerization, which support its potential use as a suitable optical controlled probe. $E$ isomer of PRLC ${ }_{4} \mathrm{OAzo}$ proved to be more effective ACE inhibitor $\left(\mathrm{IC}_{50}=1.08 \mu \mathrm{M}\right)$ than its aza-stilbene structural analogue. These preliminary studies suggest the importance in the rational design for the optimization of the interaction at the enzyme binding sites and performed azoderivatives as promising candidate compounds for the development of new multifunctional drugs for the treatment of AD. Further experiments are currently under progress to evaluate in vitro enzymatic response of $\mathrm{Z}$ isomer PRLC $\mathrm{C}_{4} \mathrm{OAzo}$. 
Acknowledgments: This work was supported by CONICET (National Scientific and Technical Research Council), ANPCyT (National Agency for Promotion of Science and Technology) and UNS (Universidad Nacional del Sur).

\section{References}

1. McHardy, S.; Wang, H.; McCowen, S.; Valdez, M. Recent advances in acetylcholinesterase Inhibitors and Reactivators: An update on the patent literature (2012-2015). Expert Opin. Ther. Pat. 2017, 27, 455-476.

2. Chen, X.; Wehle, S.; Kuzmanovic, N.; Merget, B.; Holzgrabe, U.; König, B.; Sotriffer, C.A.; Decker, M. Acetylcholinesterase Inhibitors with Photoswitchable Inhibition of $\beta$-Amyloid Aggregation. ACS Chem Neurosci. 2014, 5, 377-389, doi:10.1021/cn500016p.

3. Reisinger, B.; Kuzmanovic, N.; Löffler, P.; Merkl, R.; König, B.; Sterner, R. Exploiting protein symmetry to design light-controllable enzyme inhibitors. Angew. Chem. Int. Ed. 2014, 53, 595-598.

4. Broichhagen, J.; Frank, J.A.; Trauner, D. A roadmap to success in photopharmacology. Acc. Chem. Res. 2015, 48, 1947-1960.

5. Broichhagen, J.; Jurastow, I.; Iwan, K.; Kummer, W.; Trauner, D. Optical Control of Acetylcholinesterase with a Tacrine Switch. Angew. Chem. Int. Ed. 2014, 53, 7657-7660.

6. Agnetta, C.; Decker, M. Photoresponsive Hybrid Compounds. In Design of Hybrid Molecules for Drug Development, 1st ed.; Decker, M., Ed.; Elsevier Ltd.: Amsterdam, The Netherlands, 2017; Volume 11, pp. 279-315.

7. Biscussi, B.; Menéndez, C.; Appignanesi, G.A.; Gerbino, D.C.; Murray, A.P. XXI SINAQO; Organizado por la Sociedad Argentina de Investigación en Química Orgánica (SAIQO): Potrero de los Funes, San Luis, Argentina, 2017; p. 239.

8. Sequeira, M.A.; Herrera, G.; Quirolo, Z.; Dodero, V. Easy Directed Assembly of only Nonionic Azoamphiphile Builds up Functional Azovesicles. RSC Adv. 2016, 6, 108132-108135, doi:10.1039/C6RA20933E.

9. Okuno, H.; Wei, W.H.; Tomohiro, T.; Kodaka, M. Selective Synthesis and Kinetic Measurement of 1:1 and 2:2 Cyclic Compounds Containing 1, 4, 7, 10-Tetraazacyclododecane and Azobenzene Units. J. Org. Chem. 2000, 65, 8979-8987.

10. Willstatter, R.; Benz, M. Zur Kenntniss der 'Azophenole Chem. Ber. 1906, 339, 3492.

11. Jaeger, C. Ueber das Azophenol. Berichte Der Deutschen Chemischen Gesellschaft 1875, 8, 1499.

12. Ellman, G.L.; Courtney, K.D.; Andres, V.; Featherstone, R.M. A new and rapid colorimetric determination of acetylcholinesterase activity. Biochem. Pharmacol. 1961, 7, 88-95.

13. Alza, N.P.; Richmond, V.; Baier, C.J.; Freire, E.; Baggio, R.; Murray, A.P. Synthesis and cholinesterase inhibition of cativic acid derivatives. Org. Med. Chem. 2014, 22, 3838-3849.

14. Benedini, L.A.; Sequeira, M.A.; Fanani, M.L.; Maggio, B.; Dodero, V.I. Development of a Nonionic Azobenzene Amphiphile for Remote Photocontrol of a Model Biomembrane. J. Phys. Chem. B 2016, 120, 4053-4063.

15. Biscussi, B.; Murray, A.P. Síntesis de análogos de aza-resveratrol con actividad anticolinesterasa. In Proceedings of the XXVI JJI Jornada de Jóvenes Investigadores AUGM, Universidad Nacional de Cuyo, Mendoza, Argentina, 17-19 October 2018. Available online: http://bdigital.uncu.edu.ar/13200 (accessed on 8 November 19).

(C) 2019 by the authors. Licensee MDPI, Basel, Switzerland. This article is an open access article distributed under the terms and conditions of the Creative Commons Attribution (CC BY) license (http://creativecommons.org/licenses/by/4.0/). 